PETAR PUHMAJER

Hrvatski restauratorski zavod Zagreb

ppuhmaje@h-r-z-.hr

ŽELJKO TRSTENJAK

Konzervatorski odjel u Varaždinu

zeljkotrs@gmail.com
Primljeno: 27. 02. 2019.

Prihvaćeno: 17. 09. 2019.

DOI: $10.21857 / \mathrm{m} 8 \mathrm{vqrtz} 309$

\title{
POVIJEST, ARHITEKTURA I OBNOVA PALAČE KEGLEVIĆ
}

U članku se govori o povijesti izgradnje i obnovama palače Keglević u Varaždinu. Razmatraju se njezina razvojna, prostorna i oblikovna obilježja s obzirom na arhivske izvore, rezultate konzervatorskih istraživanja te sačuvanost struktura. Identificira se povijest naručitelja i kasnijih vlasnika. Valorizira se njezin značaj u kontekstu stambene arhitekture Varaždina 18. stoljeća, a poseban osvrt govori o konzervatorskoj obnovi palače u ovom stoljeću.

\section{UVOD}

Palača Keglević (sl. 1) istaknuta je građevina sjevernog obodnog područja gradske jezgre Varaždina. Glavnim je pročeljem okrenuta prema Nazorovoj ulici, s formiranim manjim predvrtom, ali u regulacijskoj liniji s drugim kućama, dok je istočno pročelje uz bočnu, Fallerovu ulicu. Sjeverno od palače pruža se njezino prostrano dvorište. Urbanistički smještaj palače bio je predodređen položajem nekadašnjih prometnica na prilazu gradu i prvotnom izgradnjom područja van gradskih zidina, gdje se građevna struktura postupno podiže krajem 17., a osobito u 18. stoljeću, s prestankom ratnih opasnosti. Tom je izgradnjom formirano sjeverno podgrađe, a današnja Nazorova ulica nazivala se Sjeverno grabište (Fossatum Septentrionale) jer je vodila uz rub sjevernog šanca varaždinske tvrđave. ${ }^{1}$

1 IVy LENTIĆ KUGLI, Varaždin nakon požara 1776. godine, Zagreb, 1973. 
Planovi grada s početka 19. stoljeća (sl. 2 i 3) pokazuju da je palača i u rano vrijeme svog nastanka imala dvorište i vrt sa sjeverne strane. U njemu se nalazila jedna gospodarska zgrada, položena u smjeru istok-zapad, dok je današnja u smjeru sjever-jug te uz rub parcele, pa je očito sagrađena kasnije. Vrt se nadovezivao u produžetku parcele prema sjeveru, a njegova ograđena površina je bez naznačene organizacije, što ukazuje da je bila riječ o povrtnjaku ili voćnjaku. ${ }^{2}$

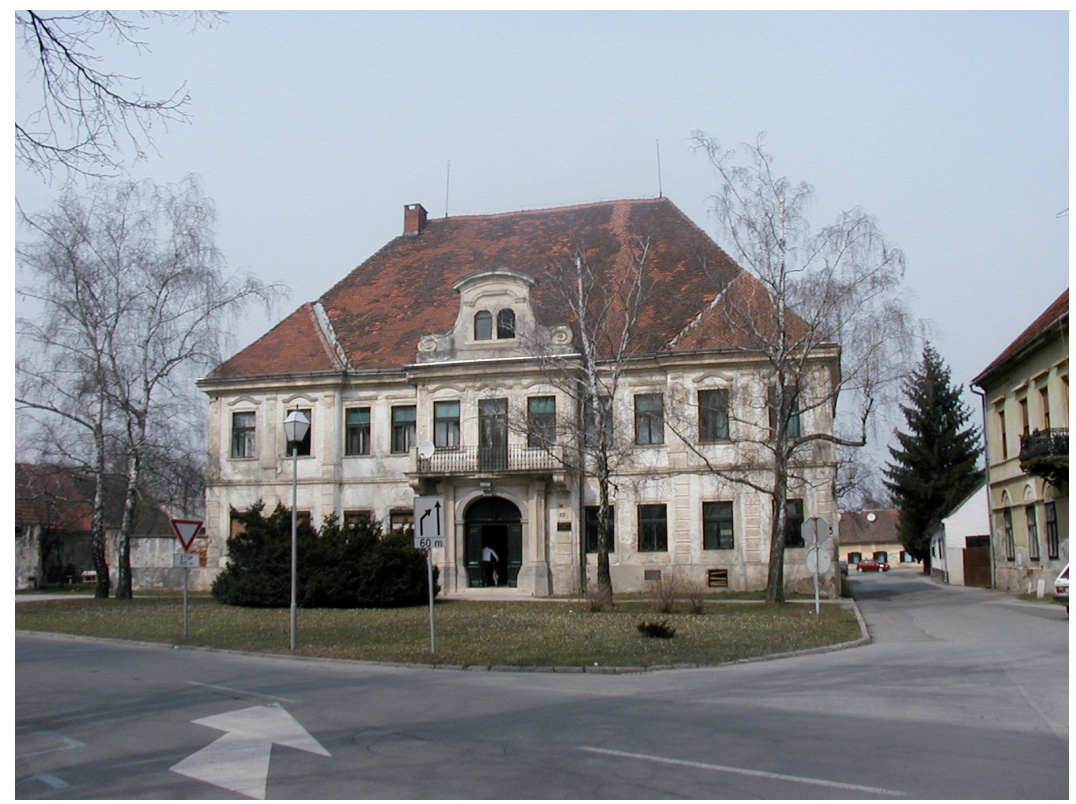

Slika 1. Palača Keglević, stanje 2002.

\section{NARUČITELJ I OKOLNOSTI GRADNJE}

Poznato je da je obitelj Keglević posjedovala kuću u Sjevernom podgrađu koja se prvi put spominje 1700. godine kao vlasništvo grofa Petra Keglevića. lako zapisi govore da se ona nalazila blizu crkve sv. Florijana, ${ }^{3}$ s obzirom na sporadičnu izgradnju, i oskudne arhivske podatke i slikovne prikaze, teško je sa sigurnošću

2 Beyschlagov plan iz 1807. godine pokazuje da su palača i vrt označeni istim kućnim brojem 422, ali je dvorište naznačeno bijelom bojom, kao i okolne ulice, a vrt zelenom te ima ucrtano raslinje. Vrt je tek nešto detaljnije prikazan na veduti J. Podhraczkog iz 1823. godine.

3 Mira ILIJANIĆ, "Prilog istraživanju historijsko-urbanističke dokumentacije Varaždina", u: Mira Ilijanić. Urbanizam - graditeljstvo - kultura. Zbornik radova, Varaždin, 1999., 44. 
reći je li riječ o današnjoj lokaciji. Neki povjesničari sugeriraju da jest jer se već u prvoj polovini 18. stoljeća, kod današnjeg ugla s Fallerovom ulicom, spominje kuća u vlasništvu Keglevića. ${ }^{4}$ Ona je zabilježena na Vötterovu planu grada između 1770. i 1773., ${ }^{5}$ a izvori spominju da je 1773. na kratko prešla u ruke zagrebačkih biskupa. ${ }^{6}$ Iste je godine vlasnikom postao grof Josip Keglević (1741.-1813.), koji je navodno već i prije posjedovao tu kuću. ${ }^{7}$ Budući da je grof Keglević 1763. oženio Rozaliju, rođakinju biskupa Franje Thauszyja, smatra se da je kuću povratno dobio kao miraz. ${ }^{8}$ Grof Keglević je 1774. poduzeo obnovu i dogradnju ove kuće u palaču. ${ }^{9}$

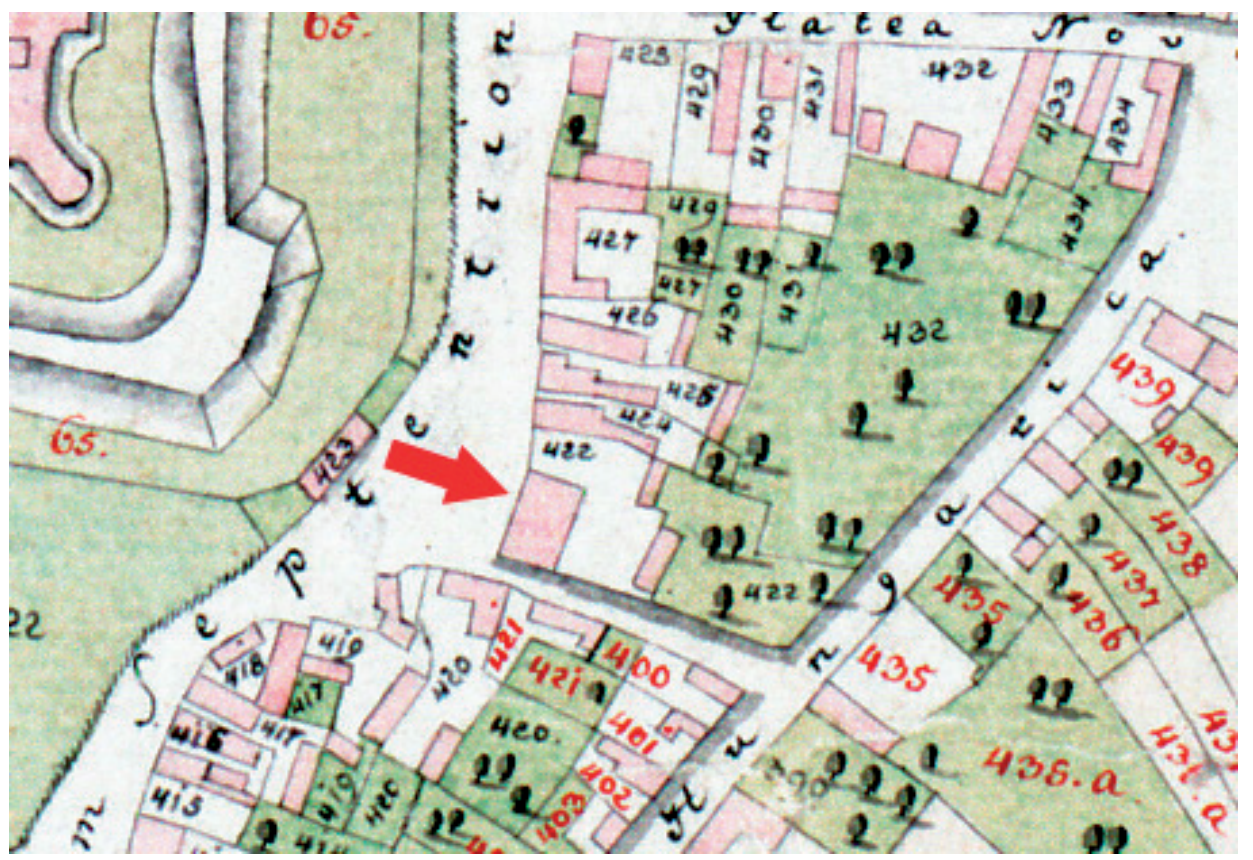

Slika 2. Palača Keglević na Beyschlagovu planu grada iz 1807. godine

(Hrvatski državni arhiv)

4 Ivy LENTIĆ KUGLI, Zgrade varaždinske povijesne jezgre, Zagreb, 2001., 106.

5 Plan prikazuje samo uski dio sjevernog podgrađa te nisu naznačene pojedinačne građevine, ali su na pojedinim mjestima upisani nazivi, poput kapele (sv. Florijana, op.a.), Tridesetnice, kuće Keglević i Niczky. Usp. Mirela SLUKAN ALTIĆ, Povijesni atlas gradova. V. svezak: Varaždin, Zagreb, 2009., 269.

6 Adolf WISSERT, "Bilješke o nekim varaždinskim kućama”, Spomenica varaždinskog muzeja 19251935, Varaždin, pretisak 1995., 52.

7 Ivy LENTIĆ KUGLI, 2001., n. dj., 106.

8 Ivy LENTIĆ KUGLI, 2001., n. dj., 106. i Baltazar Adam KRČELIĆ, Annuae ili Historija 1748-1767, Zagreb, 1952., 446-47.

9 Ivy LENTIĆ KUGLI, Varaždinski graditelji i zidari 1700-1850, Zagreb, 1981., 27. 


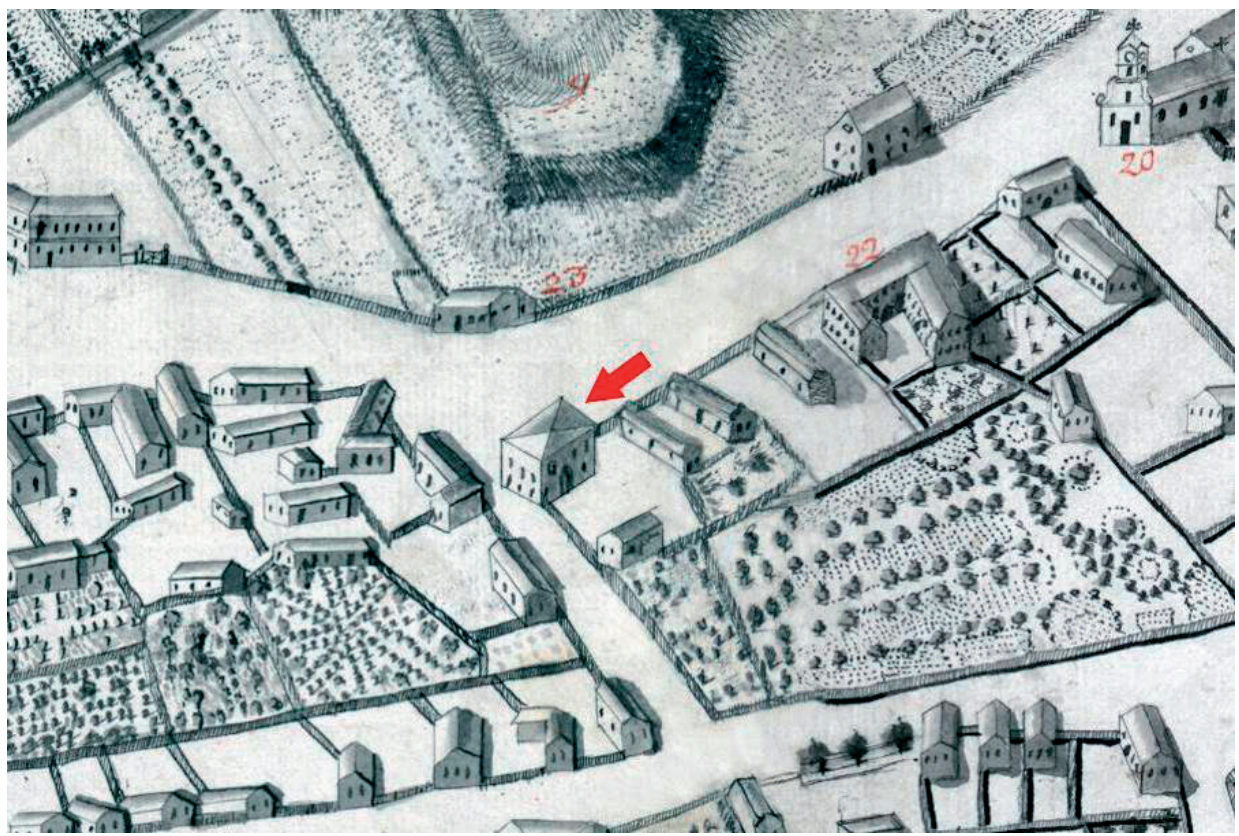

Slika 3. Palača Keglević na veduti J. Podhraczkog iz 1823. godine

(Országos Széchényi Könyvtár, Budimpešta)

O Josipu III. Kegleviću, naručitelju palače, postoji više povijesnih podataka, a sačuvan je i njegov portret iz kasnih godina (sl. 4). ${ }^{10}$ Bio je mlađi sin Aleksandra Keglevića (1706.-oko 1750.) i Kristine Marije Ratkaj, ${ }^{11}$ školovan se na Hrvatskom kolegiju u Beču (1758.-59.). ${ }^{12} \mathrm{U}$ više navrata spominje ga znameniti kroničar Baltazar Adam Krčelić, koji piše da je Josip bio član Namjesničkog vijeća, odnosno svojevrsne hrvatske vlade, a time i pripadnik političke i društvene elite. Oženio se, dakle, Rozalijom Thauszy (oko 1747.-1782.), kćeri biskupova siromašnog sluge, koji je tvrdio da je biskupov rođak. Kako Kegleviću nije uspijevalo dugo pronaći suprugu, brak između njega i Rozalije bio je dogovoren. ${ }^{13}$ Velik dio života Keglević je proveo u svom dvorcu u Loboru.

10 Marijana SCHNEIDER, Portreti 1800 - 1870., Katalog zbirke Povijesnog muzeja Hrvatske, Zagreb, 1973., 84.

11 Vjekoslav KLAIĆ, Acta Keglevichiana. Annorum 1322.-1527., Zagreb, 1917., LXXVIII-LXXXIII.

12 Kamilo DOČKAL, Hrvatski kolegij u Beču 1624.-1784., Wien-Zagreb, 1996., 332, 334.

13 Baltazar Adam KRČELIĆ, 1952., n. dj., 446-447. 


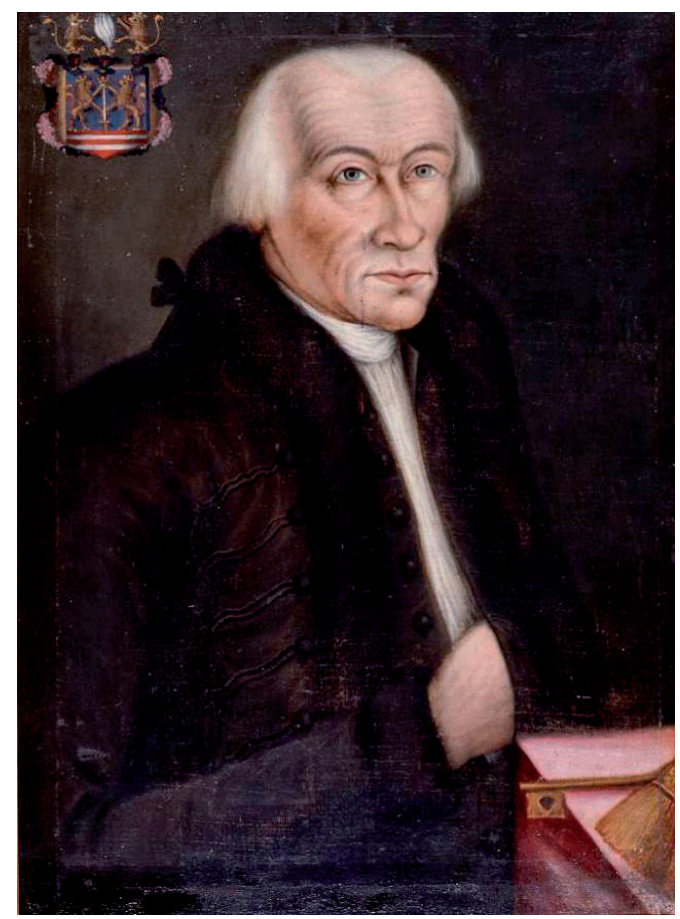

Slika 4. Portret Josipa III. Keglevića (Hrvatski povijesni muzej)

Izgradnju nove gradske palače Keglević je povjerio 1774. godine istaknutom varaždinskom arhitektu i graditelju Jakovu Erberu. ${ }^{14}$ Arhivski zapisi otkrivaju da Erber nije dovršio poslove u cijelosti pa je došlo do spora, pri čemu je grof pristao platiti za onaj dio koji je bio dovršen. ${ }^{15}$ Glavnina današnje građevne strukture palače u načelu se može datirati u to vrijeme budući da prostorna organizacija, kao i oblikovanje pročelja, odgovara arhitekturi sedamdesetih godina 18. stoljeća. Pretpostavljamo da su od ranije kuće preostale tek poneke zidne strukture koje dosadašnjim istraživanjima nije bilo moguće utvrditi, ali i da su one u cjelokupnoj današnjoj građevnoj strukturi posve zanemarive.

14 Jakov Erber (Štajerska, oko 1716. - Varaždin, 1776.) bio je glavni gradski inženjer i graditelj u Varaždinu u trećoj četvrtini 18. stoljeća. Projektirao je i sagradio brojne građevine. Nalazimo ga kod gradnje palače Varaždinske županije (1769.-70.), krila uršulinskog samostana (1772.), vlastite kuće (1771.72.), Dijačkih i Opatičkih gradska vrata (1773.), kripte u kapeli sv. Florijana (1773.), gradske ubožnice (1774.), te nadogradnje gradske vijećnice (1775/76.). Izvan Varaždina radi arhitektonske snimke Tridesetnice u Nedelišću (1774.) i Solane u Čakovcu, kao i projekt za solanu u Háromfi u Mađarskoj, prema tipskom nacrtu Ugarske komore. Ivy LENTIĆ KUGLI, 1981., n. dj., 21-31.

15 Ivy LENTIĆ KUGLI, 1981., n. dj., 27. 


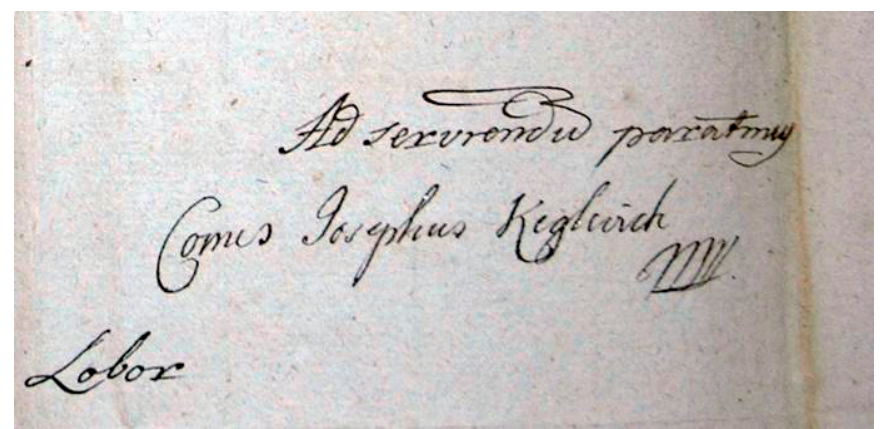

Slika 5. Potpis Josipa Keglevića na dokumentu iz 1775. godine (Državni arhiv u Varaždinu)

Zapisnik gradskog magistrata od 4. veljače 1775. bilježi da je Erber dužan magistratu 100 forinti, te da grof Josip Keglević duguje Erberu za zidarske poslove 150 forinti. Na Erberovu je molbu donesena odluka da će se zatražiti od Keglevića da isplati dug izravno gradu. ${ }^{16}$ Iz Keglevićevog pisma magistratu (sl. 5) od travnju 1775. godine može se iščitati da su radovi započeti, ali nedovršeni. Kako je građevinska sezona redovito započinjala u proljeće, a završavala ujesen, može se pretpostaviti da je izgradnja palače započeta godinu dana ranije, odnosno 1774. Treba imati na umu da grof u svojoj žalbi spominje pregradnje i popravke (reparandae), dakle radnje na već postojećoj građevini. ${ }^{17} \mathrm{Iz}$ pisma (vidi arhivski prilog ${ }^{18}$ vidi se da su radovi tada bili u tijeku jer grof obećaje gradskim vlastima da će, čim se vrati iz Lobora, vidjeti je li majstor Erber obavio posao, i da će u skladu s time isplatiti traženi novac. ${ }^{19}$ Erber je, naime, upao u velike dugove te mu je prijetila tužba i zapljena imovine. O sporu nakon toga više ne nalazimo spomena, pa pretpostavljamo da je riješeno tako da je Keglević platio Erberu samo onaj dio posla koji je smatrao završenim.

16 Državni arhiv u Varaždinu (HR-DAVŽ), Poglavarstvo grada Varaždina (PGV), Protocollum Magistratuale Liberae, Regiaeq Civitatis Varasdinensis a 24o Aprilis Anni 1774. usq 24tam Aprilis 1775 confectum, 4. 2. 1775 ., str. 474 , točka 8 , spis 82 .

17 Ivy LENTIĆ KUGLI, 1981., n. dj., 27.

18 HR-DAVŽ, PGV, Gradski spisi, kut. CXVII - 18.

19 HR-DAVŽ, PGV, Protocollum Magistratuale..., 20. 4. 1775., točka 5, 570, točka 5. 


\section{PALAČA TIJEKOM 19. I 20. STOLJEĆA}

Grof Keglević će posjedovati palaču do 1805. godine, otprilike kada je vjerojatno prepisuje na svoga sina Tomu (1769.-1850.) te umire 1813. godine. Dvije godine kasnije, 1815. palača je prodana Ceciliji Saloczy, udovici Ivana Krstitelja Horvath de Szent Peter. Po njezinoj smrti 1830. vlasnik je Zeno Horvath koji je zatim prodaje 1838. Ignjatu Dietrichu, a njemu pripada još 1851 . godine. ${ }^{20} \mathrm{U}$ drugoj polovici 19. stoljeća, palača prelazi u vlasništvo Čazmanskog Kaptola. Čazmanski je kaptol tijekom prve polovine stoljeća imao sjedište u bivšem pavlinskom samostanu u Lepoglavi, ${ }^{21}$ a kada je samostan prenamijenjen za kaznionicu, sjedište Kaptola je preseljeno u Varaždin. Palača je na prijelazu 19. u 20. stoljeće zabilježena na staroj razglednici (sl. 6), na kojoj se, uz manje iznimke, nazire uglavnom današnje stanje vanjštine građevine.

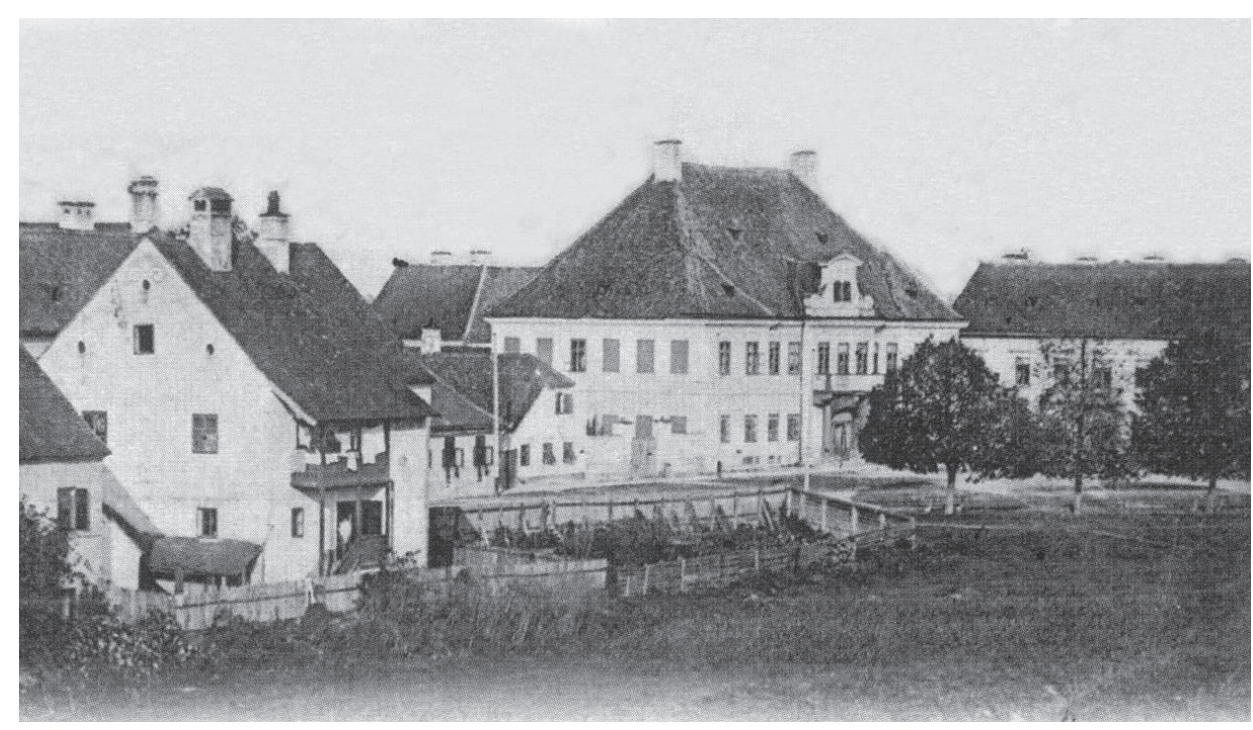

Slika 6. Palača Keglević na razglednici iz oko 1900. godine (Gradski muzej Varaždin)

20 Ivy LENTIĆ KUGLI, 2001, n. dj., 106.

21 Kamilo DOČKAL, Povijest pavlinskog samostana Blažene Djevice Marije u Lepoglavi, Zagreb, 2014. 441-448. 
Čazmanski će kaptol u palači biti sve do 1932. godine. Nakon Drugog svjetskog rata, palača je nacionalizirana, ${ }^{22}$ unutrašnjost je pregrađena u manje stanove, a u istočni dio prizemlja smješten je Zavod za znanstveni rad HAZU Varaždin. Šezdesetih godina 20. stoljeća zgrada je upisana u registar zaštićenih spomenika kulture. U stručnoj valorizaciji 1966. detaljno je opisano stanje unutrašnjosti i vanjštine zgrade, a tada se spominju i manji popravci. ${ }^{23}$ Godine 1998. izrađen je arhitektonski snimak postojećeg stanja zgrade u mjerilu 1:50, ${ }^{24}$ kao temelj za buduću obnovu i zahvate. Godine 2004. u sklopu povrata crkvene imovine, palača je dodijeljena Varaždinskoj biskupiji, ${ }^{25}$ koja je 2007. pokrenula njezinu obnovu.

\section{PROSTOR I OBLIKOVANJE PALAČE U SVJETLU KONZERVATORSKO-RESTAURATORSKIH ISTRAŽIVANJA}

Palača je jednokrilna, podrumljena katnica, pravokutnog tlocrta i vrlo visokog četverostrešnog krova. Uvid u izvorna prostorna i oblikovna obilježja je, osim vizualnim opažanjem, bilo moguće dobiti i konzervatorsko-restauratorskim istraživanjima. Pokazalo se da su prostori obje etaže bili narušeni raznim adaptacijama u 20. stoljeću pa je čak i sam glavni salon u katu bio pregrađen na tri manje prostorije, od kojih je jedna služila kao sanitarni čvor (sl. 7 i 8). U prizemlju nije rađeno sondiranje jer su prostorije bile u funkciji, no već prema debljini zidova i položaju otvora mogla se relativno lako razlučiti izvorna situacija od naknadnih pregradnji. ${ }^{26}$

22 Ivy LENTIĆ KUGLI, 2001., n. dj., 106.

23 Godine 1960. djelomično je popravljen pokrov krova te je riješena odvodnja, a šest godina kasnije zgrada je priključena na gradski vodovod. Ivy LENTIĆ KUGLI, Popis i opis kuća u Varaždinu, rukopis, Gradski muzej Varaždin, Varaždin, 1963.-67., Nazorova 14 - Palača Keglević.

24 Naručitelj je bilo Gradsko poglavarstvo Varaždina, a izvođač Conex d.o.o. (projektant B. Marić). Izrađeni su tlocrti svih etaža, pročelja, te dva poprečna i jedan uzdužni presjek. Dokumentacija se čuva u Konzervatorskom odjelu u Varaždinu.

25 Vesna MARGETIĆ SLATKI, "Zavod HAZU seli iz palače Keglević", Regionalni tjednik. Sjeverozapadna Hrvatska, Varaždin, 19. 3. 2007.

${ }^{26} U$ elaboratu je stoga predloženo da se sondiranje unutrašnjosti prizemlja provede prije samog izvođenja radova. 

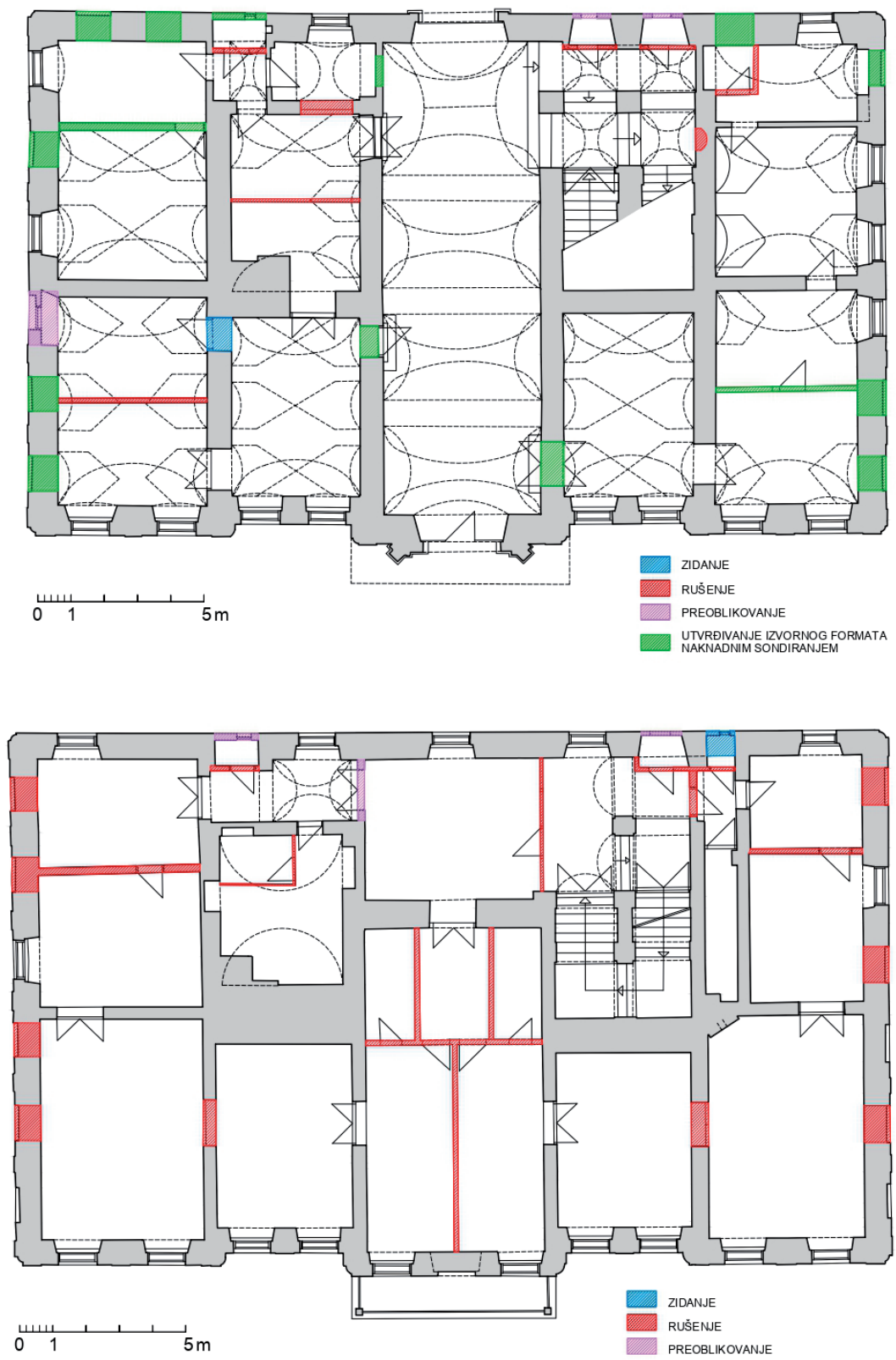

Slika 7. i 8. Tlocrt prizemlja i prvog kata, prijedlog rušenja i zidanja prema konzervatorskim nalazima, 2002. 

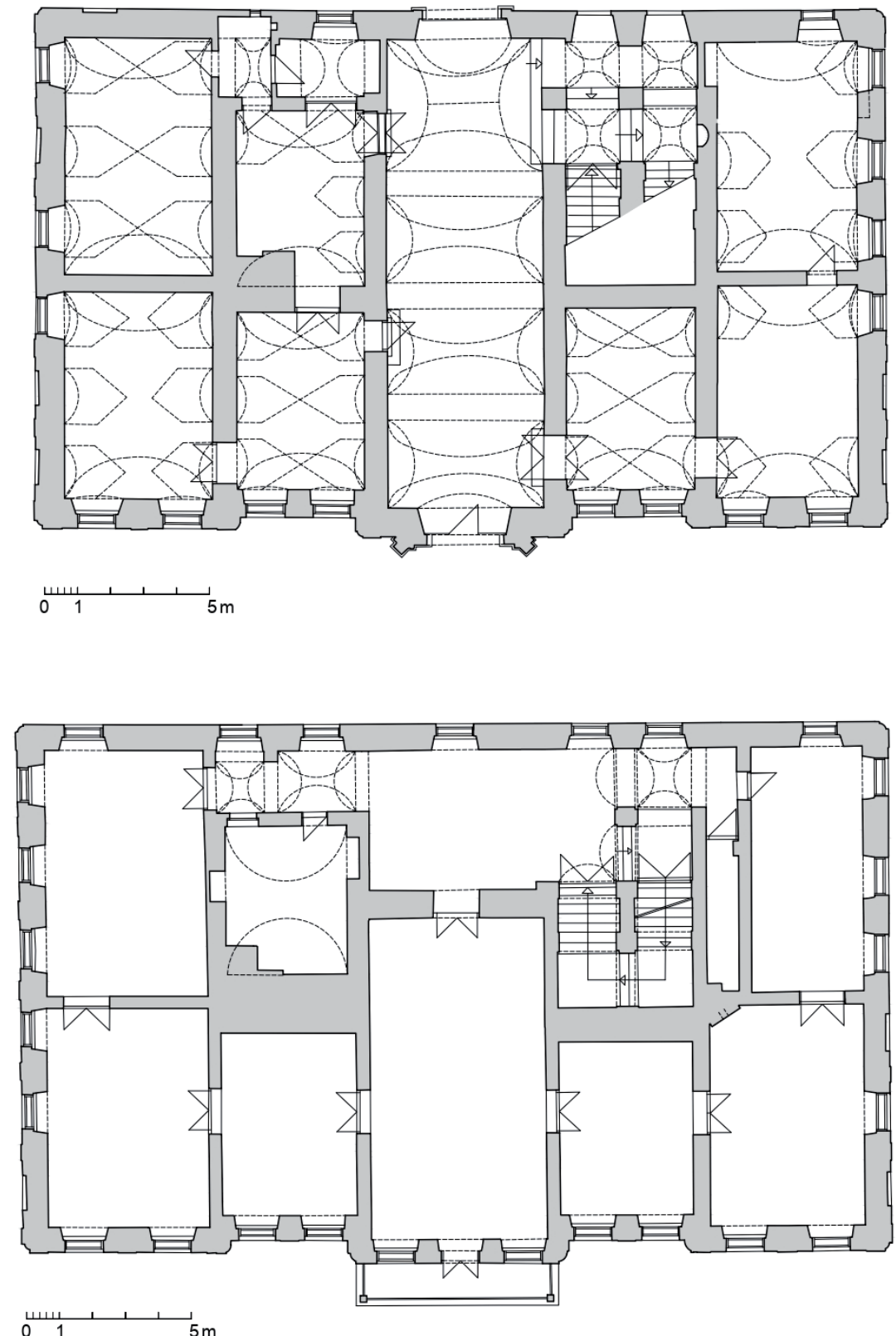

Slika 9. i 10. Tlocrt prizemlja i prvog kata, prijedlog prezentacije. 

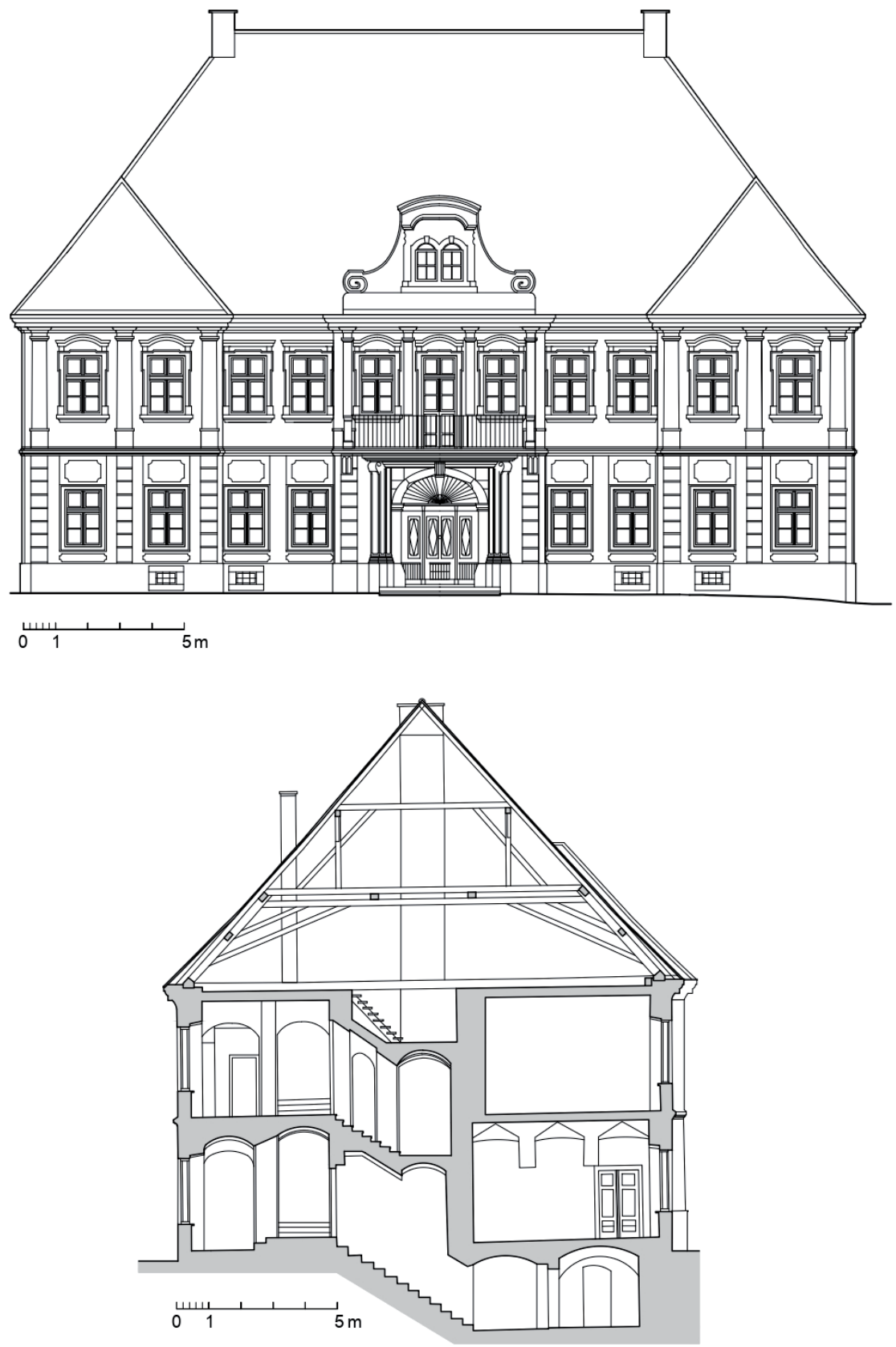

Slika 11. i 12. Glavno (južno) pročelje i poprečni presjek, prijedlog prezentacije. 
Prostornu organizaciju svake etaže čini središnja, osovinski smještena prostorija, u prizemlju veža, a na katu glavni salon i predvorje, uz koje se bočno, s obje strane, grupiraju po četiri prostorije $(s l .9,10,11)$. Koncept grupiranja prostorija, kod velikih stambenih palača, obilježje je zrelobaroknog doba. ${ }^{27}$ Za razliku od ranijeg razdoblja kada su prostorije bile nanizane uz arkadni hodnik, sada se javlja potreba za većim komforom, koji se ostvarivao međusobnom povezanošću prostorija vratima, bez hodnika, poput stanova, te sustavom grijanja koji je omogućavao toplinu u više prostorija. Prostorni raspored u tome podsjeća na druge varaždinske plemićke kuće 18. stoljeća, ali se kod palače Keglević uočava izrazita tendencija k tlocrtnoj simetriji. ${ }^{28}$

Prostorije prizemlja presvođene su bačvastim svodovima s lomljenim susvodnicama, izuzev veže i stubišta, gdje su češke kape, a cijeli kat većinom ima ravne stropove, osim nekolicine čeških svodova i jedne prostorije $s$ bačvastim svodom. ${ }^{29}$ Bačvasti je svod naknadno sagrađen u vremenu kad je ta prostorija služila kao kuhinja, zasigurno u 19. stoljeću. Prvi je kat bio reprezentativni stambeni prostor, piano nobile, pa prostrane prostorije imaju velike prozore koji su osiguravali mnogo dnevnog svijetla, a glavni salon i izlaz na balkon s pogledom na grad. Najraščlanjeniji dio unutrašnjosti je stubište koje se prema prizemlju i katu rastvara lukovima, ${ }^{30}$ a krakovi su raspoređeni konvergentno, doduše, s nekoliko odmorišta i razina. Na zidu drugog odmorišta pronađena je zazidana, polukružno zaključena niša za skulpturu, ${ }^{31}$ što je općenito karakteristični element stambenih palača 18 . stoljeća. ${ }^{32}$

27 Petar PUHMAJER, Barokne palače u Varaždinu, doktorska disertacija, Filozofski fakultet u Zagrebu, Zagreb, 2012., n. dj., 73-74.

28 Petar PUHMAJER, 2012., n. dj., 78, 312.

29 Svođene prostorije ima i podrum koji se prostire ispod cijelog zapadnog dijela kuće te manjim dijelom južnog i istočnog dijela. Dvije su prostorije podruma svođene bačvastim svodom, a sve ostale češkim kapama.

30 Predvorje prvog kata bilo je rastvoreno dvostrukim lukom stubišnog prostora $s$ istočne strane, a u istim dimenzijama utvrđena su dva zazidana lučna otvora na zapadnoj strani. S obzirom na izrazite pregradnje, nije bilo moguće utvrditi je li riječ o identičnim lukovima, pri čemu bi predvorje onda bilo raščlanjeno lukovima s istočne i zapadne strane, a time i znatno prošireno u odnosu na današnje stanje. Stoga pretpostavljamo da je tako veliki negrijani hodnički prostor, ukoliko je uopće prvotno tako funkcionirao, morao biti dokinut već u ranije vrijeme.

31 Petar PUHMAJER, Palača Keglević u Varaždinu. Elaborat konzervatorsko-restauratorskih istraživanja, Arto d.o.o., Zagreb, studeni 2008., n. dj., 30.

32 Dvije takve niše za skulpturu nalaze se na odmorištu stubišta palače Patačić u Varaždinu (1764.), a nalazimo ih i u kući Petra Nepomuka Sermagea u Ćirilometodskoj 4 u Zagrebu (oko 1777.), gdje su dvije, bogato oblikovane, kamene rokajne vaze. Niše na stubištima su česte i u stambenim palačama Graza i Beča u 18. stoljeću. 
U unutrašnjosti palače nije sačuvana izvorna oprema iz 18. stoljeća, a izuzetak su jednostavni, uleknuti žbukani ukrasi na svodovima veže i stubišta. ${ }^{33} \mathrm{U}$ samom salonu nisu pronađene starije zidne slike, već tek nekoliko šablonskih slikarija 19. ili 20. stoljeća, a u dvije istočne prostorije, u najstarijem sloju, koji vjerojatno pripada 18. stoljeću, zidovi su bili obojeni u bijelo. Prvotna dekorativna obrada zidova mogla je svakako podrazumijevati i zidne obloge, poput drvenih oplata ili tapeta. S kraja 19. i početka 20. stoljeća, dakle iz vremena kada je u palači Čazmanski kaptol, sačuvana je vrijedna stolarija uklađenih vrata i tri secesijske kaljeve peći. ${ }^{34}$

Pročelja palače (sl. 12) imaju tipično oblikovanje i stil treće četvrtine 18. stoljeća pa arhitektonska dekoracija sadrži motive školjki, rokaja, palmete i bogatu florealnu ornamentiku. To je tipična dekoracija štajerske arhitekture koja je dominantna u sjeverozapadnoj Hrvatskoj u tom vremenu, a sam koncept pročelja odgovara drugom značajnom djelu Štajerca Jakova Erbera, a to je palača Varaždinske županije koja je netom prije toga dovršena (1770.)..$^{35}$ Obje imaju tri rizalita i zaključni zabat s udvojenim prozorom, a najveće sličnosti vide se u oblikovanju portala. ${ }^{36} \mathrm{Na}$ oba je središnja zona konveksno istaknuta te dekorirana motivom ovula koji kontinuira duž vijenca. lako je Erber autor projekta za obje građevine, portale su klesali različiti klesari jer se vide znatne razlike u obradi detalja. Kod Keglevićeva je pročelja također zanimljivo da se na relativno maloj plohi javljaju čak tri rizalita. Uspostavom velikih prozora na relativno maloj plohi pročelja došlo je do dodirivanja prozorskih okvira s rizalitnim istacima, a rezultat je vrlo bogato, tektonski raščlanjeno pročelje. Srednji rizalit zaključen je volutnim zabatom koji ima gotovo dominantnu ulogu $u$ artikulaciji ${ }^{37}$ te se uvođenjem prozora na njemu pokušao sugerirati funkcionalni odnos između unutrašnjosti i vanjštine, međutim, iza zabata se nalazi tek neuređen tavanski prostor. ${ }^{38}$

Istraživanjima 2007. bila su obuhvaćena i pročelja palače, pri čemu su ispitani izvorni formati otvora, detalji profilacija, te obrada kamena, žbuke i boje.

33 Prema riječima stanara, navodno se na stropu prostorija u katu nekad nalazila jednostavna štukatura u obliku profilacija.

34 Petar PUHMAJER, 2008., n. dj., 13-17.

35 Petar PUHMAJER, 2012., n. dj., 186-187.

36 Petar PUHMAJER, 2012., n. dj., 99, 116-117.

37 Volutni zabati karakteristični su za više građevina iz tog razdoblja. Usp. Petar PUHMAJER, "Palača Zagrebačkog kaptola u Varaždinu", Radovi Instituta za povijest umjetnosti, 33, 2009., 170.

38 Petar PUHMAJER, 2012., n. dj., 99. To, dakako, ne znači da je ono zato manje vrijedno, nego upravo suprotno, ono odražava najsuvremenije stilske tendencije u 18. stoljeću kada su kazalište i kulisa često bili inspiracija za prostorna i oblikovna rješenja u arhitekturi. 
Pokazalo se da su prozori prizemlja izvorno bili manjeg formata nego današnji, odnosno da su naknadno produljeni prema dolje, pa im je s donje strane dokinut rubni profil. Produljenjem prozora ugrađena je i nova stolarija s dekorativnim željeznim rešetkama, tipičnima za kraj 19. ili početkom 20. stoljeća. Sukladno pregradnjama u unutrašnjosti u to doba, brojni su prozori na pročeljima u prizemlju i katu zazidani te su zadržani kao slijepe niše.

Pročelja su izvorno bila ožbukana, dakako, vapnenom žbukom, a ispitivanje sastava pokazalo je da je žbuka koju čine dekorativni elementi bila zasićena vapnom, radi bolje čvrstoće, dok je na ravnim plohama imala znatno manje vapna pa je s tih dijelova, dobrim dijelom i otpala. Pojedini su detalji naknadno bili prežbukani i pojednostavljeni, osobito na krovnom zabatu, gdje su uklonjene i kamene vaze koje su nekad počivale na ugaonim volutama.

Sondiranjem je utvrđeno i izvorno obojenje. Kao prvi i najstariji sloj pokazao se ton nazvan blijedorumeni oker. Riječ je o vapnenoj boji u koju je dodano malo crvenog pigmenta, željeznog oksida, što je rezultiralo vrlo svijetlom plohom blijedoružičastog tona. ${ }^{39}$ Ovo je obojenje prekrivalo sve površine pročelja, žbukane i kamene elemente, ravne dijelove i ukrase, pa je pročelje u osnovi bilo monokromno. ${ }^{40}$ Cilj je bio, na izvjestan način, dematerijalizirati zidnu površinu koja je izrazito bogato raščlanjena. Izvorni ton, kako se pokazalo nakon izvedbe, bio je izuzetno svijetao pa je nijansa ovisila o dobu dana i vremenskim uvjetima varirajući od bijele u doba najjače sunčeve svijetlosti do svijetložute u kasno popodne i predvečer. Monokromna obrada pročelja blijedoružičastim tonom odraz je stilskih i umjetničkih kretanja u razdoblju rokokoa za koje su karakteristični meki i nježni oblici te pastelne boje.

\section{PRVA (2007.-2008.) I DRUGA (2016.-2017.) FAZA KONZERVATORSKE OBNOVE PALAČE}

Slijedom inicijative da se u palaču Keglević smjesti sjedište novoosnovane Varaždinske biskupije, prišlo se 2007. uređenju i obnovi zgrade. Stvorene su tada, također okolnosti da se obnova palače, po prvi puta u njenoj povijesti, izvede u

39 Ton je utvrđen pod brojem 007 na ton-karti „Silikatne žbuke i premazi“ proizvođača Samoborka iz 2006. godine. Petar PUHMAJER, 2008., n. dj., 31, 109.

40 U 18. stoljeću u kontinentalnoj Hrvatskoj, najčešće su bila bikromna pročelja, odnosno jednobojne ravne plohe s bijelo bojenim detaljima. Uglavnom su to bile bijela, žuta, crvena, siva i crna, a s pojavom rokokoa, javlja se čitav niz ružičastih pročelja. Takva je izvorno bila i palača Varaždinske županije (Usp. Marijana KORUNEK, Blanda MATICA, Željko TRSTENJAK, “Obnova palače Varaždinske županije s osvrtom na povijesni razvoj županije kao institucije", Godišnjak zaštite spomenika kulture Hrvatske, 33/34, 2009.-2010., 72), najvažnije djelo graditelja Jakova Erbera te još nekoliko građevina u Varaždinu. 
cijelosti prema konzervatorskim načelima, što je osigurala stalna koordinacija i nadzor Konzervatorskog odjela u Varaždinu. Godine 2007. i 2008. izvedeni su radovi statičke sanacije i obnove krovišta, što možemo nazvati prvom fazom obnove, dok je nastavak uslijedio tek 2016.-2017. kada je obnovljeno glavno pročelje i dvorišni zid, što bi bila druga faza obnove. Iduća, treća faza, kojom bi se radovi završili, još do danas nije započela, a trebala bi u budućnosti obuhvatiti obnovu svih ostalih pročelja, uređenje unutrašnjosti i okoliša.

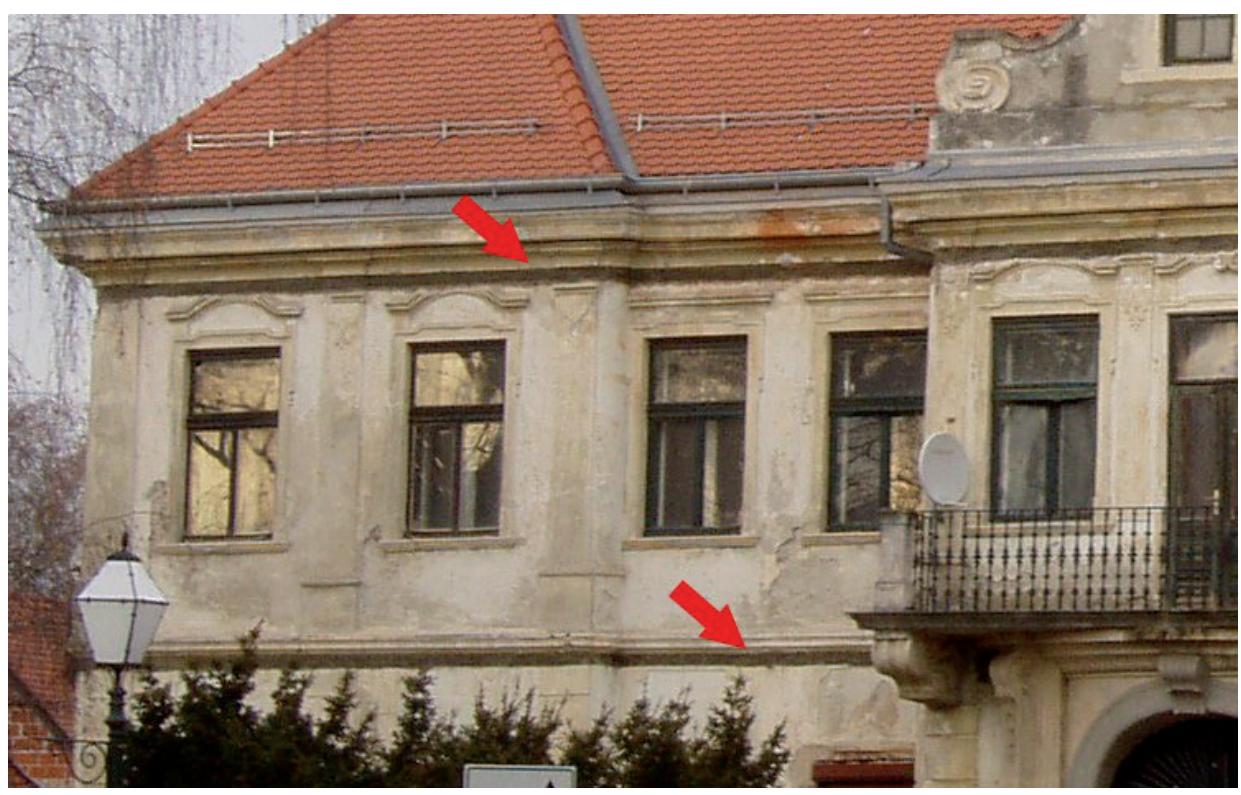

Slika 13. Ugrađena karbonska vlakna na južnom pročelju, u svrhu statičke sanacije, snimljeno 2009.

Statička sanacija izvedena 2007.-2008. godine, bila je nužna radi uočenih pukotina u ziđu, a podrazumijevala je učvršćenje perimetralnih zidova u prizemlju i katu ugradnjom karbonskih vlakana u vodoravnim potezima duž gornjih dijelova ziđa svake etaže (sl. 13). Isto tako, uklonjeni su naknadni pregradni zidovi u prvom katu te su ponovo uspostavljene veće prostorije, kao i nekadašnja prostorija glavnog salona u svom punom formatu. Prizemlje nije bilo obuhvaćeno radovima jer je još uvijek u funkciji. 


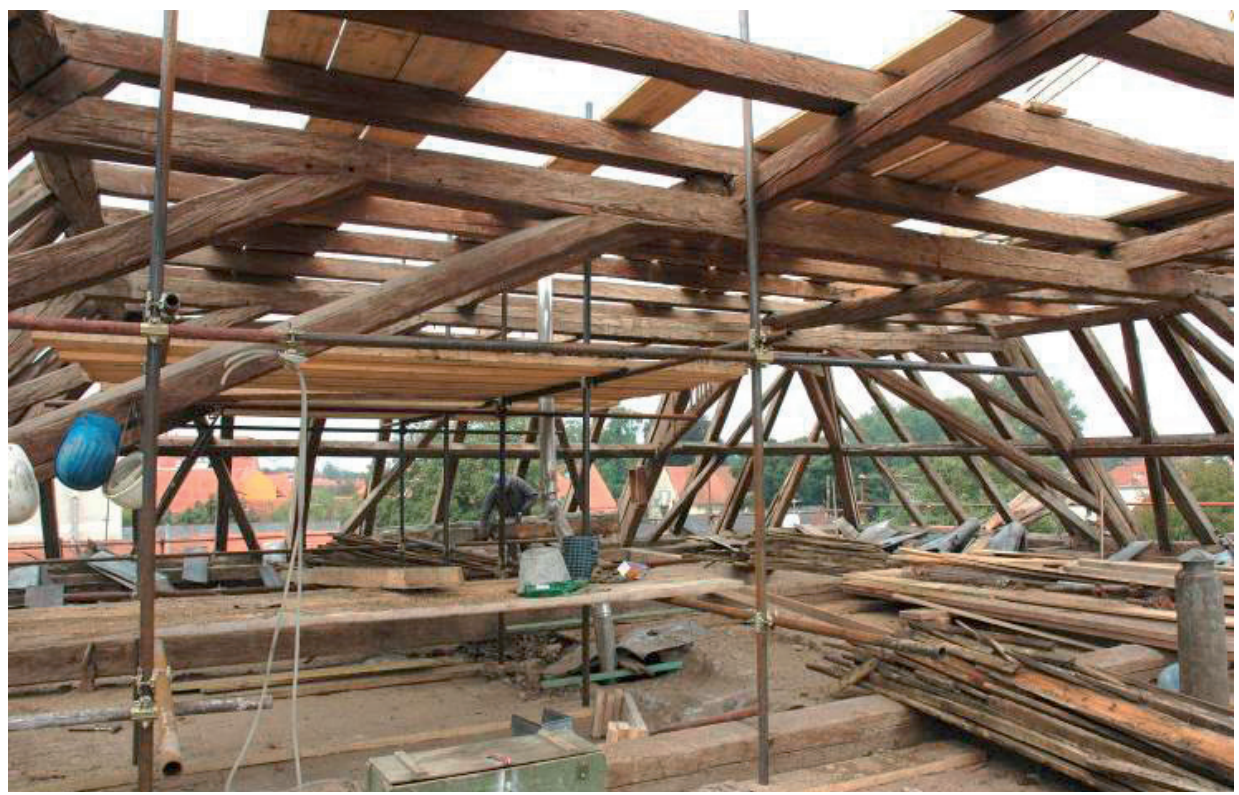

Slika 14. Razgradnja starog krovišta, 2008.

Drvenu konstrukciju krova (sl. 14), koja je bila izrazito stara i trošna, zbog dotrajalosti nije bilo moguće sačuvati pa je izrađen projekt novog krovišta. ${ }^{41}$ Staro krovište je razgrađeno, saniran je završni vijenac te je sagrađeno novo krovište istih proporcija. Predviđena je u budućnosti i rekonstrukcija dvaju velikih dimnjaka na uglovima krovnog sljemena nakon što se definira novi sustav grijanja u palači. Planirani radovi prve faze su izvedeni u cijelosti, ali je zbog izostanka daljnjeg priljeva financijskih sredstava, došlo do prekida u aktivnostima oko obnove, te su radovi nastavljeni tek devet godina kasnije.

Druga faza obnove odvijala se 2016.-2017. godine uređenjem glavnog pročelja i dvorišnog zida palače. Radovi su započeli restauratorskim tretiranjem brojnih kamenih detalja na pročelju, portala, prozorskih okvira, balkona i dijelova zabata. Oni su mjestimice bili jako oštećeni pa su krpani, zapunjavani i obrađivani, a u manjoj mjeri zamijenjeni novim ulomcima kamena.

41 Projektant ovih radova bio je Tomislav Kovačić, ing. arh. i tvrtka Arto d.o.o. iz Novog Marofa, a radove na novom krovištu izveo je Zidarski, tesarski i fasaderski obrt „Graditelj“ iz Gornje Poljane. Konzervatorski nadzor obavljali su djelatnici Konzervatorskog odjela u Varaždinu. 
Velika oštećenja bila su i na samoj žbuci. Pokazalo se da je na više mjesta žbuka naknadno popravljana, a brojni detalji grubo prežbukani bez poštivanja izvornih oblika profilacija, te je bilo nužno izvesti korekcije detalja. Budući da su prozorima u prizemlju promijenjeni formati, odnosno prvotno manji prozori su bili prošireni u veće te su im izvađeni vjerojatno prvotni kameni okviri i oblikovani novi, u žbuci, postavilo se pitanje što s činjenicom da prozorima nedostaje donji okvir. Tim više jer se ispod njega nalazi istaknuti pravokutni medaljon zasječenih uglova. Nadalje, htjelo se sačuvati stolariju s dekorativnim željeznim rešetkama iz 19. stoljeća, pa još u izradi prijedloga prezentacije nije bilo predviđeno smanjivanje formata prozora na prvotnu veličinu. Tako je odlučeno da će se žbukani okvir s bočnih strana produljiti i uz donji rub prozora, a ornament na parapetu neznatno suziti (sl. 15 i 16). Ako se u budućnosti utvrdi egzaktan izgled i format okvira, prilikom svake promjene stolarije bit će moguće napraviti odgovarajuću korekciju.
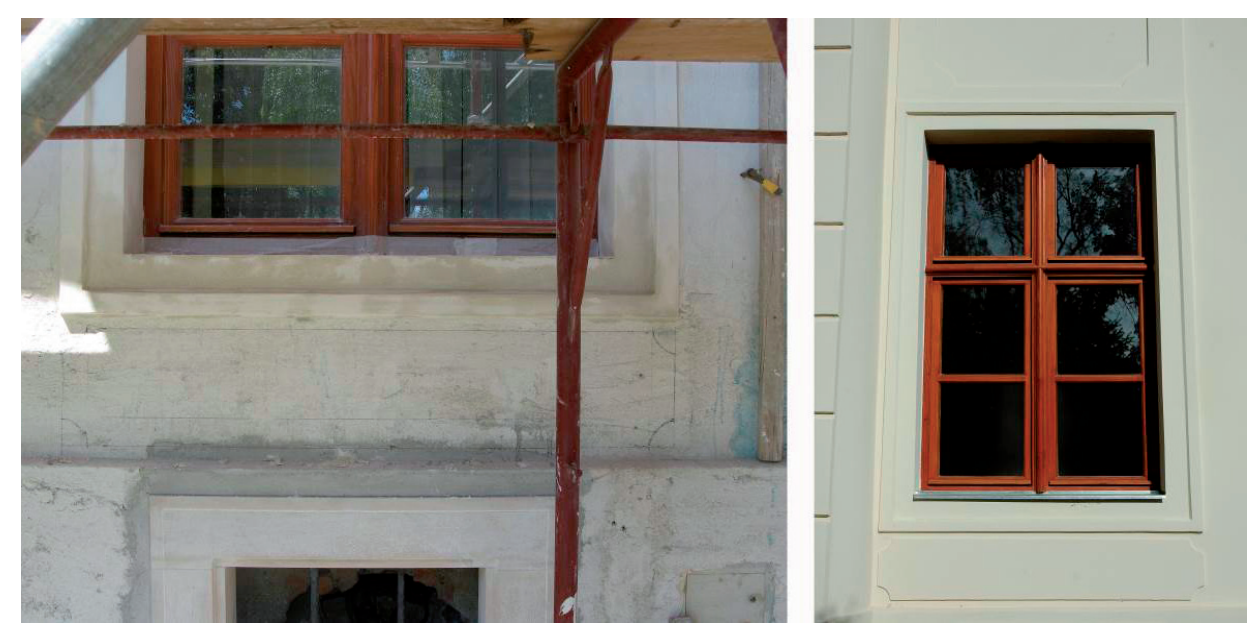

Slika 15 i 16. Olovkom naznačeno mjesto za izvedbu žbukanog medaljona ispod prozora u prizemlju tijekom radova 2017. i prozor s novom stolarijom i izvedenim medaljonom na parapetu, nakon radova 2018. godine

Na zabatu, odnosno krovnoj kućici, žbukani su detalji tek u manjem dijelu sačuvali izvornu geometriju pa se prišlo rekonstrukciji prozorske nadstrešnice prema sačuvanom detalju (sl. 17 i 18). Pri tome je bilo nužno poznavati povijesne profilacije $u$ arhitekturi tog vremena kako bi se detalj izveo s maksimalnom vjerodostojnošću. U tu svrhu su izrađene izvedbene skice, a prema njima i šablone vodilice koje su zidari koristili prilikom izvođenja na pročelju. Budući 
da je istraživanjima utvrđeno izvorno obojenje pročelja, uzet je egzaktan uzorak nijanse boje s ton-karte te se izvođač obvezao ponoviti istovjetni ton, što je bez greške i izvedeno (sl. 20). ${ }^{42}$

$\mathrm{Na}$ pročeljima je sačuvana izvorna stolarija s kraja 18. jedino na vratima glavnog portala, koja je u obnovi restaurirana. Zatečena prozorska stolarija s početka 20. st. pokazala se izuzetno trošnom te ju nije bilo moguće očuvati. Odlučilo se izvesti novu, sa šesterodjelnim rasporedom letvica i okana te je položiti na unutrašnju stranu prozorske niše, što je karakteristično za barokno razdoblje. Novi su prozori (vidi sl. 16) oblikovanjem i položajem tako bliži izvornom izgledu, ali su im ugrađena dvostruka stakla kako bi se osigurali tehnički uvjeti očuvanja topline i njihova trajnost.
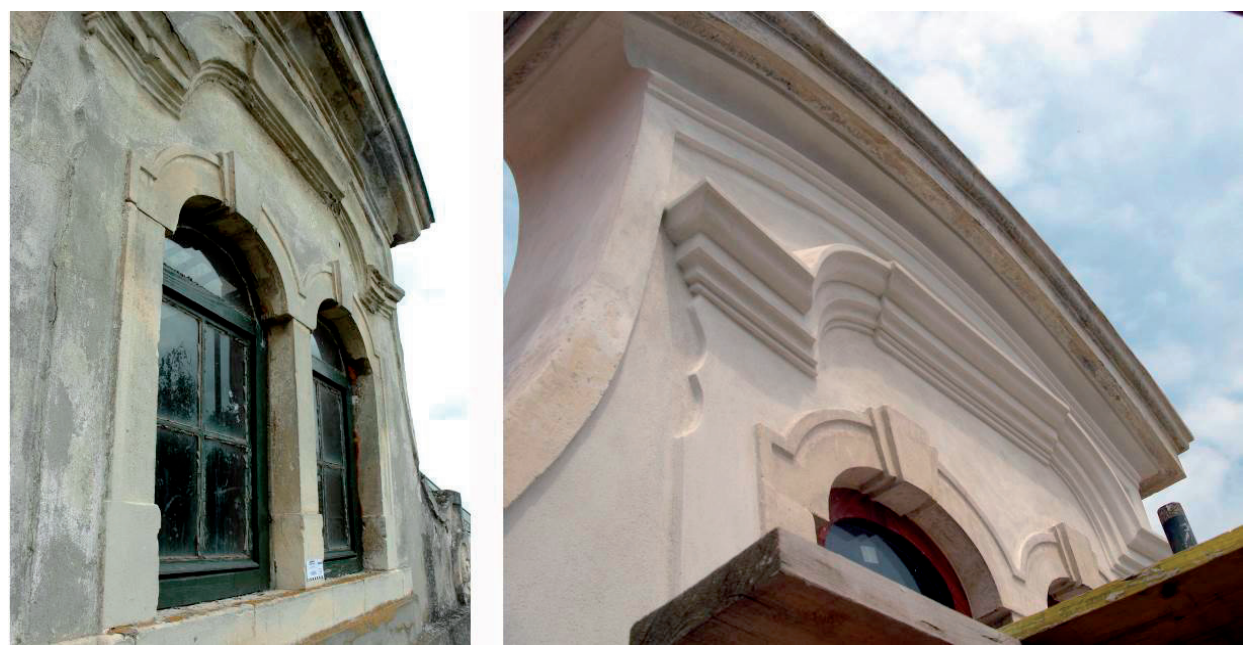

Slika 17. i 18. Krovna kućica (zabat) prije radova 2008. te nakon žbukanja i izvedbe korekcije profilacija 2017.

Saniran je i dvorišni opečni zid na kojemu su rešetkasta željezna vrata zamijenjena novim drvenima, punih ploha, a saniran je i jedan od dvaju kolobrana koji se uz njih nalazio (sl. 19). ${ }^{43}$ Preostaje dovršiti obnovu ostalih pročelja te unutrašnjosti što bi trebalo uslijediti idućih godina.

42 Fasaderske radove izvela je tvrtka Švenda građenje d.o.o.

43 Ovi su kolobrani zanimljivi po tome jer nisu ugrađeni u portal ili ugao zgrade nego se nalaze uz stupce portala, položeni u zemlju. Takvi se javljaju u 19. stoljeću, ali isključivo od željeza i to u gradskim sredinama gdje su ulice i pločnici bili popločani, dok su ovi na palači Keglević od klesanog kamena i tipičnog oblika profilirane puž-volute, karakteristične za 18. stoljeće. Usp. Petar PUHMAJER, 2012., n. dj., 126-127. 


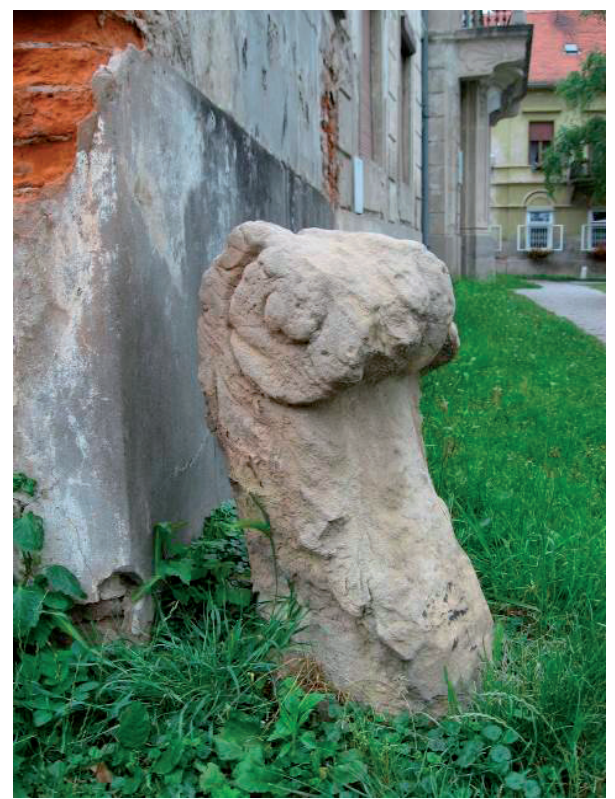

Slika 19. Kolobran kod dvorišnog ulaza, 2007.

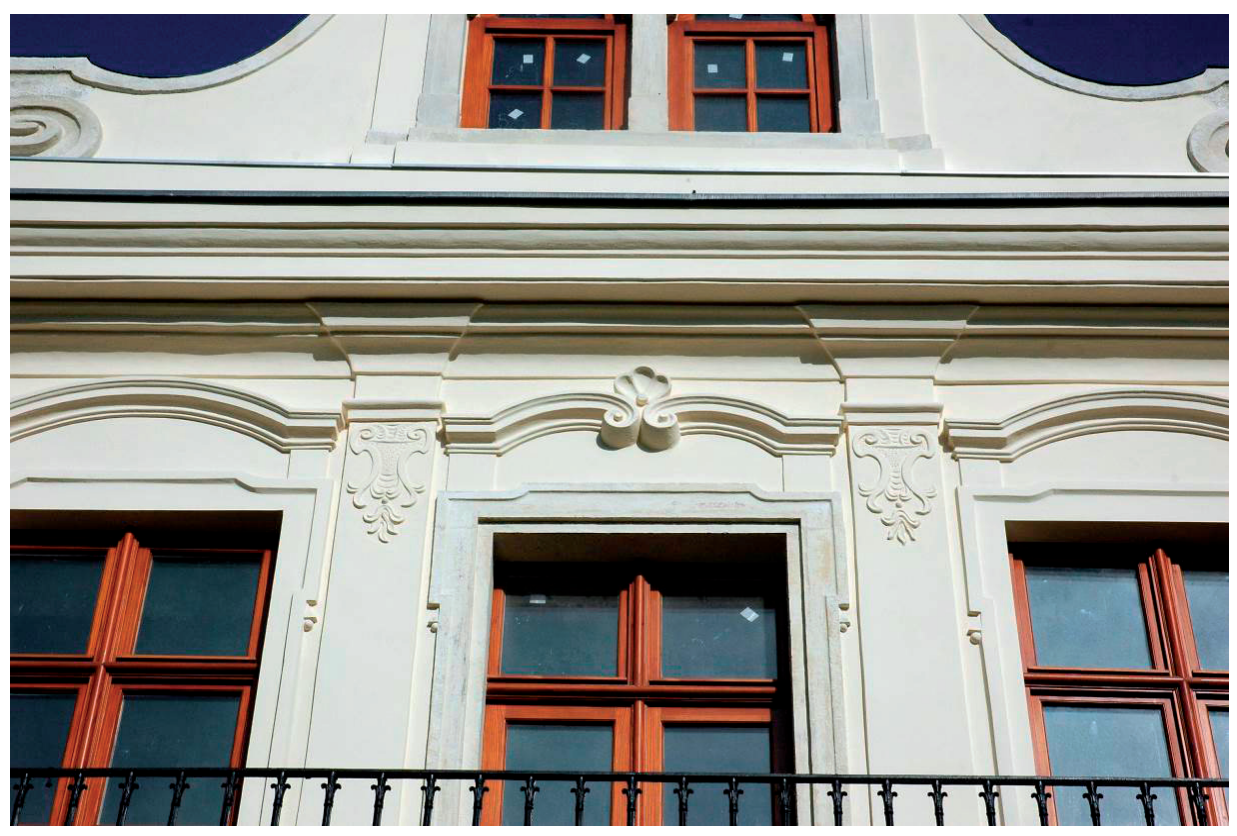

Slika 20. Izvedeni ton boje na pročelju, u kasnopopodnevnom svjetlu, 2018. 


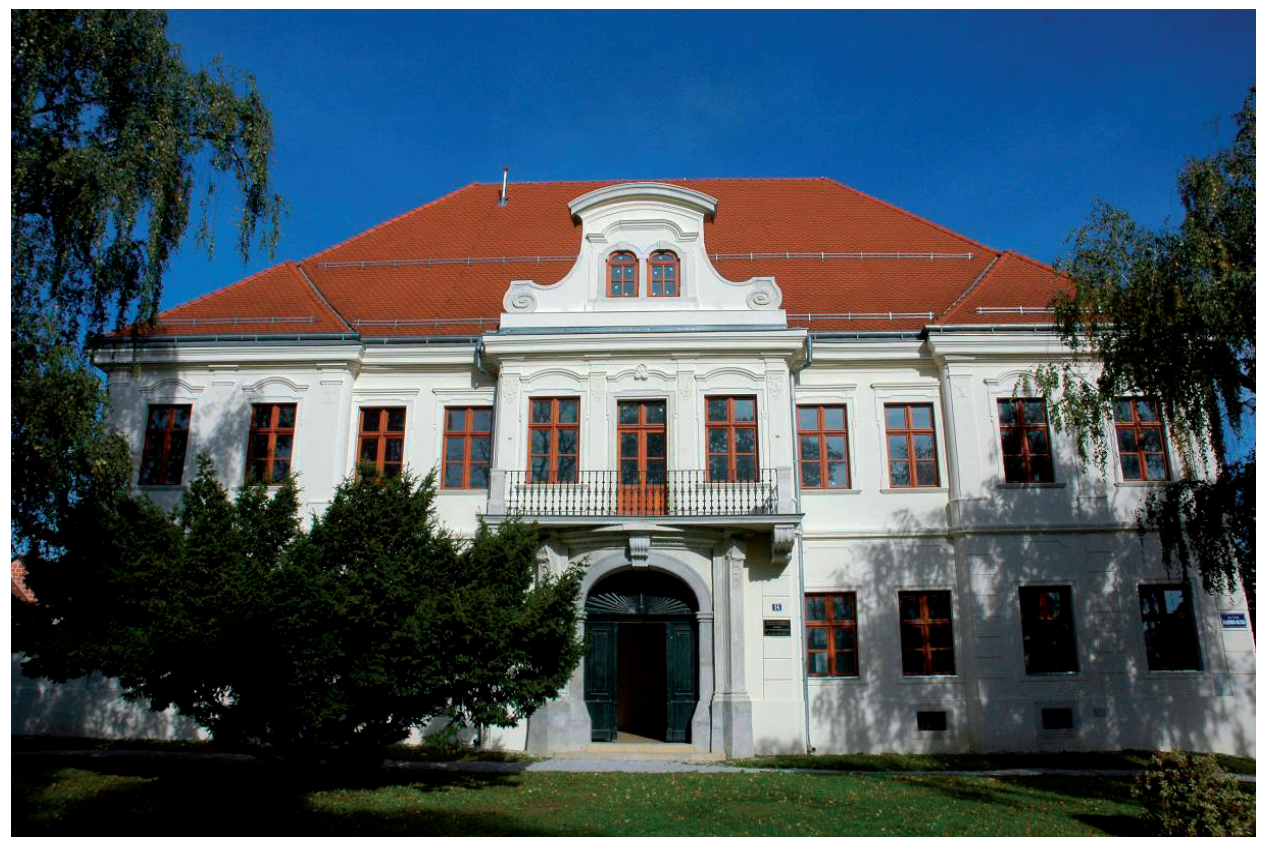

Slika 21. Pročelje nakon obnove, 2018.

U dosadašnjoj obnovi palače Keglević suočili smo se s uobičajenim izazovima konzervatorske struke. Prvenstveno je bilo nužno izvesti rekonstrukciju elemenata koji su u raznim adaptacijama dokinuti ili promijenjeni. U unutrašnjosti je ponovno uspostavljen nekadašnji prostorni raspored s velikim salonom, te izvorni formati više prostorija, a na glavnom pročelju su izvedene bitne korekcije detalja te je ono time u velikoj mjeri približeno svom prvotnom izgledu (sl. 21).

Palača Keglević vrijedno je djelo barokne arhitekture Varaždina i Hrvatske. lako malih dimenzija, ističe se kvalitetnom prostornom organizacijom i raščlambom koja u cijelosti odražava suvremene tendencije u arhitekturi toga vremena. Osim arhitektonske, ona ima i urbanistički značaj. Kao takva je već ranije bila prepoznata, a sukladno tome i zaštićena kao kulturno dobro. Upravo su te odrednice bile ključne u namjeri da se obnovi palače u najnovije vrijeme pristupi u cijelosti prema konzervatorskim načelima. 


\section{|ZVORI}

1/ Državni arhiv u Varaždinu, fond Poglavarstvo grada Varaždina.

2/ Gradski muzej Varaždin, zbirka razglednica, dokumentacija.

3/ Hrvatski državni arhiv, zbirka planova i nacrta.

4/ Országos Széchényi Könyvtár.

\section{LITERATURA}

1/ Kamilo DOČKAL, Hrvatski kolegij u Beču 1624.-1784., Wien-Zagreb, 1996.

2/ Kamilo DOČKAL, Povijest pavlinskog samostana Blažene Djevice Marije u Lepoglavi, Zagreb, 2014.

3/ Mira ILIJANIĆ, Prilog istraživanju historijsko-urbanističke dokumentacije Varaždina, u: Mira Ilijanić. Urbanizam - graditeljstvo - kultura. Zbornik radova, Varaždin, 1999.

4/ Marijana KORUNEK, Blanda MATICA, Željko TRSTENJAK, "Obnova palače Varaždinske županije s osvrtom na povijesni razvoj županije kao institucije", Godišnjak zaštite spomenika kulture Hrvatske, 33/34, 2009.-2010., 55-78.

5/ Baltazar Adam KRČELIĆ, Annuae ili Historija 1748-1767, Zagreb, 1952.

6/ Ivy LENTIĆ KUGLI, Popis i opis kuća u Varaždinu, rukopis, Gradski muzej Varaždin, Varaždin, 1963.-67., Nazorova 14 - Palača Keglević.

7/ Ivy LENTIĆ KUGLI, Varaždin nakon požara 1776. godine, Zagreb, 1973.

8/ Ivy LENTIĆ KUGLI, Varaždinski graditelji i zidari 1700-1850, Zagreb, 1981.

9/ Ivy LENTIĆ KUGLI, Zgrade varaždinske povijesne jezgre, Zagreb, 2001.

10/ Vesna MARGETIĆ SLATKI, "Zavod HAZU seli iz palače Keglević", Regionalni tjednik. Sjeverozapadna Hrvatska, Varaždin, 19. 3. 2007.

11/ Petar PUHMAJER, Barokne palače u Varaždinu, doktorska disertacija, Filozofski fakultet u Zagrebu, Zagreb, 2012.

12/ Petar PUHMAJER, Palača Keglević u Varaždinu. Elaborat konzervatorsko-restauratorskih istraživanja, Arto d.o.o., Zagreb, studeni 2008.

13/ Petar PUHMAJER, "Palača Zagrebačkog kaptola u Varaždinu", Radovi Instituta za povijest umjetnosti, 33, 2009., 163-178.

14/ Marijana SCHNEIDER, Portreti 1800 - 1870., katalog zbirke Povijesnog muzeja Hrvatske, Zagreb, 1973., 84.

15/ Mirela SLUKAN ALTIĆ, Povijesni atlas gradova. V. svezak: Varaždin, Zagreb, 2009.

16/ Adolf WISSERT, "Bilješke o nekim varaždinskim kućama”, u: Spomenica varaždinskog muzeja 1925-1935, Varaždin, pretisak 1995. 


\section{SAŽETAK}

\section{POVIJEST, ARHITEKTURA I OBNOVA PALAČE KEGLEVIĆ}

Nedavna obnova palače Keglević u Varaždinu, koja je u dvije faze trajala posljednjih desetak godina, povod je za pregled svih dosadašnjih saznanja o njenoj povijesti i arhitekturi. Palača je sagrađena 1774.-1775. za grofa Josipa III. Keglevića, prema projektu varaždinskog graditelja Jakova Erbera. Tlocrtna dispozicija govori o zrelobaroknom rješenju organizacije prostorija koje se grupiraju na svakoj etaži, što je odraz komfornog stanovanja 18. stoljeća. Konzervatorska istraživanja ukazala su na izvorne i naknadne promjene u organizaciji prostora, te tehničke aspekte oblikovanja i obojenja pročelja koje je izuzetno bogate raščlambe, s kamenim i žbukanim ukrasima, trima rizalitima, portalom i balkonom. Dosad izvedenim konzervatorskim radovima, koji su obuhvatili statičku sanaciju, zamjenu krovišta i obnovu glavnog pročelja, nastojalo se maksimalno očuvati sve bitne povijesne i arhitektonske značajke palače.

Ključne riječi: arhitektura; barokna arhitektura; 18. stoljeće; Varaždin; palača Keglević, Josip Keglević, obnova.

\section{SUMMARY}

\section{HISTORY, ARCHITECTURE AND CONSERVATION OF THE KEGLEVIĆ PALACE}

The renovation of the Keglević Palace in Varaždin was undertaken in two phases during the last decade. It was an occasion for an overview of all up-to-date knowledge about its history and architecture. The palace was built for count Josip Keglević III in 1774-1775 by a Varaždin builder and architect Jakov Erber. The floor plan of the palace shows a high-baroque space organization, with rooms grouped on every floor, and concentrated around the central axe, which is a reflection of the comfortable 18th-century living standards. The research conducted in 2008 revealed the original characteristics and subsequent changes in the palace structure, technical aspects of its design, as well as the façade coloring. The façades boast lavish articulation with three projecting blocks, portal, balcony, stone and plaster decorations, and was originally painted monochrome in bright white-pinkish color typical of the rococo period. The renovation works included structural repairs, restitution of the inner space arrangement, replacement of the old roof construction, and the restoration of the main façade. It was done with the utmost care to preserve all relevant historical and architectural features of the palace.

Key Words: architecture, baroque architecture, 18th century, Varaždin, Keglević Palace, Josip Keglević, conservation. 


\section{ARHIVSKI PRILOG:}

\section{Pismo grofa Josipa Keglevića varaždinskom Magistratu u vezi obnove njegove kuće, 10. travnja 1775.}

Državni arhiv u Varaždinu, Poglavarstvo grada Varaždina, Gradski spisi, kutija CXVII - 18.

Prijepis i prijevod: dr. sc. Šime Demo

Perillustres ac generosi Domini, mihi observandissimi!

Ad litteras praeattactarum Dominationum Vestrarum de dato 5 ta Aprilis ad me in merito promeritae Jacobi Erber, murariorum magistri, mercedis florenos 150, apud me (ut asserit) habitos, constituentis ad manus praeattactarum Dominationum Vestrarum pro excontentatione debitorum ejusdem passivorum deserviturae deponendae exaratas ac, quo decuit, honore a me perceptas, rescribendum esse duxi quod, licet quidem de lege contractus conditionati ab una parte non nisi altera parte obligationi contractualiter assumptae satisfaciente adimplere deberent, praefatus porro murariorum magister conditiones contractus mecum intuitu reparandae domus meae in gremio civitatis praeattactarum Dominationum Vestrarum situatae minus adhuc ad publicam notitiam explevisset, ac ex eo etiam mihi vel a contractu resilire, vel usque perfectum domus meae statum promeritam mercedem retinere licet integrum foret, ne tamen creditores ejusdem bona quidem fide, multum tamen incaute summas elocantes damnificentur, in quantum contractui satisfecisse dignoscetur, in tantum dumtaxat ex promerita mercede ejus pro substernendo excontentationi creditorum fundo ad manus praeattactarum Dominationum Vestrarum resignare non intermittam, a quo supersedendum usque adventum meum, ubi laborem aspicere potero, praeattactae Dominationes Vestrae solae judicabunt.

Qui in reliquo amicitiae praeattactarum Dominationum Vestrarum commendatus persevero.

Praeattactarum Dominationum Vestrarum

Ad serviendum paratissimus

Comes Josephus Keglevich, m.p.

Datum in arce mea Lobor

Die 10. Aprilis 1775. 
Presvijetloj i plemenitoj našoj gospodi sudcu, konzulu, kapetanu i cijelom časnom slobodnom i kraljevskom gradu Varaždinu.

\section{U Varaždinu}

Presvijetla i plemenita gospodo, kojoj sam najponizniji sluga!

S dostojnom sam smjernošću primio pismo rečenih Vaših Gospodstava od dana 5. travnja, poslano meni u vezi s deponiranjem zaslužene plaće zidarskoga majstora Jakova Erbera u iznosu od 150 forinti, koje se (kako tvrdi) nalaze kod mene, a koje je namijenio da se predaju u ruke rečenih Vaših Gospodstava i koje imaju služiti za namirenje njegovih pasivnih dugova, te sam smatrao da na nj valja odgovoriti sljedeće: Premda osobe vezane ugovornom obvezom ne moraju ispuniti ugovorom preuzetu obvezu ako je druga strana nije zadovoljila, a rečeni zidarski majstor do sada, kako je javno poznato, nije ispunio ugovorne obveze vezane za obnovu moje kuće smještene u centru grada rečenih Vaših Gospodstava, i premda mi je stoga dopušteno ili odstupiti od ugovora ili zadržati zasluženu plaću sve do dovršenja radova na svojoj kući, ipak, da ne bi njegovi vjerovnici u dobroj vjeri nepažljivo položivši velik novac pretrpjeli štetu, ja ću u onoj mjeri u kojoj budem vidio da je zadovoljio ugovorne odredbe iz zaslužene plaće odgovarajući iznos odvojiti u fond za zadovoljenje vjerovnikâ i doznačiti u ruke rečenih Vaših Gospodstava. A rečena će Vaša Gospodstva zaključiti kako će se na to morati pričekati do mojega dolaska, kada budem mogao vidjeti napredak radova.

Preporučam se ubuduće ustrajno prijateljstvu rečenih Vaših Gospodstava. spremni sluga grof Josip Keglević, v.r. Dano u mojem dvorcu Lobor Dana 10. travnja 1775. 